\title{
Using Rummy Game Method to Improve Students' Learning Activities and English Dialog
}

\author{
Supriyanto \\ State Senior High School 3 Salatiga \\ Jl. Kartini No. 34 Salatiga, Central Java, Indonesia \\ priyantompd@yahoo.co.id
}

\begin{abstract}
This classroom action research was aimed at improving students' learning activities and students' English dialog skills in the state senior high school 3 Salatiga. The research was carried out in the state senior high school 3 Salatiga from January to June 2012. The subject of the research was 38 students of grade XI natural science 2 . While the objects of research were rummy game method, students' learning activities and students' English dialog skills. This action research was conducted in two cycles. Each consisted of planning, acting, observing, and reflecting. In cycle 1 , the researcher implemented rummy game method with big groups and ready made cards while in cycle 2, the researcher applied rummy game method with small groups and student designed cards. To collect the data the researcher gave self-assessment test and performance test before the first cycle, after the first cycle, and after the second cycle. The data analysis was done by descriptive comparison namely by comparing scores in the previous condition with those of the first cycle and the second cycle. The research findings revealed that there was significant improvement of average scores in students' learning activities namely $13.8 \%$ from $56.8 \%$ in the previous condition to $70.6 \%$ in cycle 2 and in students' English dialog skill namely 5.8 from 72.7 in the previous condition to 78.5 in cycle 2 . Hence, hypothesis stating that using rummy game method is able to improve students' learning
\end{abstract}


activities and English dialog skill in the state senior high school 3 Salatiga grade XI natural science 2 even semester year 2011/2012 is proven right.

Key words: Rummy Game Method, Learning Activities, English Dialog Skill

\begin{abstract}
Abstrak
Penelitian tindakan kelas ini bertujuan untuk meningkatkan aktivitas belajar dan kemampuan berdialog dalam bahasa Inggris para siswa di SMAN 3 Salatiga. Penelitian ini dilakukan di SMAN 3 Salatiga mulai bulan Januari sampai Juni 2012. Subyek penelitian nya adalah 38 siswa kelas XI IPA 2. Sedangkan obyek penelitian adalah metode permainan remi, aktivitas belajar siswa dan keterampilan dialog berbahasa Inggris para siswa. Penelitian tindakan ini dilaksanakan dalam dua siklus. Masing-masing terdiri dari perencanaan, tindakan, observasi, dan refleksi. Pada siklus 1, peneliti menerapkan metode permainan remi dengan kelompok-kelompok besar dan siap memainkan/membuat kartu sedangkan pada siklus 2, peneliti menerapkan metode permainan remi dengan kelompok-kelompok kecil dan kartu yang dirancang siswa.Untuk mengumpulkan data, peneliti memberikan tes pencapaian diri/selfassessment dan uji kinerja sebelum dan sesudah siklus pertama dan setelah siklus kedua.

Analisis data dikerjakan dengan perbandingan deskriptif yaitu dengan membandingkan nilai-nilai dalam kondisi sebelumnya dengan nilai-nilai siklus I dan siklus II. Hasil penelitian menunjukkan bahwa ada peningkatan yang signifikan nilai rata-rata aktivitas belajar yaitu $13,8 \%$ dari 56,8\% pada kondisi sebelumnya menjadi $70,6 \%$ pada siklus 2 dan keterampilan berdialog bahasa Inggris siswa yaitu 5,8 dari 72,7 pada kondisi sebelumnya menjadi 78,5 pada siklus 2 . Oleh karena itu,hipotesis yang menyatakan bahwa menggunakan metode permainan remi mampu meningkatkan aktivitas belajar siswa dan keterampilan dialog bahasa Inggris di SMAN 3Salatiga kelas XI IPA 2 semester genap tahun 2011/2012 terbukti benar.
\end{abstract}

Kata Kunci: Metode Permainan Remi, Kegiatan Belajar, Keterampilan Berdialog Bahasa Inggris 


\section{Introduction}

It was undeniable that the teaching and learning process for English dialog skill in the state senior high school 3 Salatiga still tended to run conventionally. Usually, Instruction began with apperception by asking and answering questions orally which led to certain topics. Besides, the teacher sometimes also used related pictures to arouse more questions and answers. Then the teacher gave dialog texts containing expressions to be learned. Based on the text the teacher developed guiding questions leading to the expressions to be learned. The teacher usually asked general information, participants, the relation among the participants, time and place, topic, and specified expressions used in the dialog.

After that the teacher, by using the charts containing expressions and responses to be learned, gave speech model and gives necessary explanation. The students repeated the teacher's speech model classically, in groups, and even individually. Next, the students were given opportunities to practice performing dialog using expressions they just learned in pairs. Finally, the teacher gives necessary correction and feedback.

Such learning model could not develop students' skill in English dialog optimally. The students, in fact, could not speak English fluently and appropriately in accordance with real context. They faced difficulties in finding and using certain expressions that matched to the situation. They were lack of expressions or gambits for variation. They got difficulties to find suitable words to express their mind and feeling. They seemed still clumsy to pronounce correctly. In addition, they did not fully have self confidence to start and to respond in the dialog. Furthermore, 
they still looked a bit afraid to participate totally.

Besides, the students' activities in learning, according to the teacher's observation, were also still low. Some students did not listen to the lesson attentively. Many students seldom asked questions. Many students were not ready to answer the teacher's questions. Not all students repeated the teacher's speech model enthusiastically. Many students did not take their turns when the teacher gave opportunities to do. Besides, many students were reluctant to propose something, and even they hardly ever gave any comment.

Ideally, the students of the state senior high school 3 Salatiga especially grade XI Natural Science 2 were good at both written and spoken English and had intense activities in learning since they came from strictly selected students. In addition, the students of natural science were accustomed to work competitively as well as collaboratively. For those reasons, it was badly needed to create learning innovation so as to cope with the learning problems. The learning innovation that the teacher did was using rummy game method in teaching English dialog skill.

Based on the facts above, the research discusses whether rummy game method is able to improve students' learning activities and English dialog skill in the state senior high school 3 Salatiga grade XI natural science 2 even semester academic year 2011/2012.

\section{Rummy Game Method}

Rummy game method is a method used to present instructional materials by using rummy game in order to achieve the determined goals. The cards are designed in such a way that they resemble the rummy cards but they contain instructional material that will be learned. The 
instructional material includes speech functions and their expressions or gambits. There are 44 cards each set, 4 face cards containing speech functions i.e expressing love, expressing sadness/sorrow, expressing agreement, and expressing disagreement and 40 cards containing specific expressions or gambits that match to certain speech functions. There are 10 expressions for one speech function. Each card includes either one speech function or one gambit/expression.

This modified rummy game can be played with three or four players. The game is simple. First the cards are shuffled and 5 cards are dealt to ach player. One card with face up is put randomly on the table as a determiner card. The remaining cards are stacked as stock pile. The players discard one card which is suitable with the determiner card and the turn to play passes clockwise. The cards are considered suitable if they are on the same speech function. If the player does not have suitable cards, he or she must take card from the stock pile. The player who discard his card which is of highest value has right to discard his card used as a determiner card for the next round. Then other player should discard one card which is suitable with the latest determiner card. The player whose cards are used up first will be the winner while the player whose cards are last used up will be the loser.

The most important thing in this game is that the players should read the content of card loudly as they discard their card so as to practice their speech and strengthen their memory. Besides, the loser will get spontaneous punishment which involves pronouncing English such as singing English song, reading poem, saying something to someone else in order to improve students' self confidence as well as to practice pronouncing English words. 
According to Lie (2002: 46), learning groups with big groups (4 members) have many advantages. They are: easy to split into pairs, producing more ideas, capable of finishing more works, and easy to monitor. Besides, the rummy cards were fully provided by the teacher.

Rummy game with small groups means that rummy game is played by 3 players. There are some advantages with small groups. According to Lie (2002: 45), learning groups with three member have some advantages such as more opportunities to contribute, easier to form, and easier to interact. In addition, the rummy cards are designed by the students themselves in groups.

\section{Research Methodology}

\section{Setting of place and time}

This classroom action research had been done for six months from January to June 2012 in the state senior high school 3 Salatiga grade XI natural science 2 . This school is on Kartini Street No. 34 Salatiga. Meanwhile, observing and identifying problems were done in January. Designing research proposal was held in February. Writing research instruments was done in March. Giving treatment and collecting data were conducted in April and May. Analyzing and discussing collected data were executed in May. Writing research report was accomplished in June 2012.

\section{Subjects and Objects of the Research}

The subjects of this research were the students of grade XI natural science 2 of the state senior high school 3 Salatiga even semester academic year 2011/2012. The number of students was 38. It consisted of 
9 male and 29 female students. While the objects were students' learning activities, students' English dialog skill and rummy game method.

\section{Research Method}

In this research the researcher wanted to solve students' problem both in learning activities and English dialog skill by giving specific treatment to the students. For those reasons the researcher applied action research method since it has purpose to solve the problem. In this case, R.B. Burns in Burns (1999: 30) states that action research is the application of fact finding to practical problem solving in a social situation with a view to improving the quality of an action within it, involving the collaboration and cooperation of researchers, practitioners and lay men.

\section{Techniques and Instruments of Collecting Data}

The techniques of collecting data used in this research were performance test, self-assessment test, and observation. Their instruments were test questions, questioner, and observation paper.

\section{Validation and Analysis of Data}

For dialog skill test, the researcher validated the test questions by writing blue prints which matched to the indicators, basic standard, and competence standard. For students' learning activities, the researcher validated data using what the so called data triangulation as stated in Sutopo (2006: 93) In this case, the researcher compared data from three sources namely from students, collaborator, and the researcher himself. For data analysis, the researcher analyzed quantitative data by using 
descriptive comparison namely by comparing test in previous condition with posttest in cycle 1 , and posttest in cycle 2 .

\section{Performance Indicators}

The research was considered successful if $80 \%$ or 31 students had high learning activities, $90 \%$ or 35 students had reached passing grade (75), and the average score of English dialog skill was 77.

\section{Research Procedures}

The research was conducted in two cycles. Each cycle consisted of four steps. They were planning, acting, observing and reflecting. Pretest was executed before treatment in cycle 1 and posttests were done after treatment in cycle 1 and treatment in cycle 2. Self-assessment tests were given before cycle 1 , after cycle 1 , and after cycle 2 . The treatment in cycle 1 needed two meetings while the treatment in cycle 2 needed four meetings. Each meeting spent 2 x 45 minutes.

\section{Planning}

The planning which was done both in cycle 1 and in cycle 2 were designing lesson plan, preparing rummy game equipment, making assessment instruments, observation paper, and arranging schedule. Rummy game equipment included rummy cards, scoring paper, speech function and gambit list, and rummy game guidelines. The differences between the first cycle and second cycle were on the number groups, instructional material, rummy card availability, and time allotment.

In cycle 1, each group consisted of four students. The instructional material included 4 speech functions namely expressing love, expressing sadness or sorrow, expressing agreement, and expressing 
disagreement. Each speech function was exemplified with ten various gambits. The rummy cards were designed by the teacher. Time allotment were 4 meetings; one meeting used for doing pretest and self-assessment test, two meetings used for giving treatment, and one meeting used for doing posttest and self-assessment test. The treatment included playing rummy game and practicing dialog using rummy cards.

In cycle 2, each group consisted of three students. The instructional material included 4 speech functions namely expressing embarrassment, expressing anger, calming down someone, and expressing annoyance. Each speech function was exemplified with ten various gambits. The rummy cards were designed by the students who were guided by the teacher. The time allotments were five meetings; four meetings used for giving treatment, and one meeting used for doing posttest and assessment test. The treatment included designing rummy cards, playing rummy game, and practicing dialog using student designed rummy cards.

Acting

In this step the teacher and the students conducted activities as it had been planned before. Firstly, the students did self-assessment test by answering questionnaire to know how intense the students did activities in teaching and learning process in the previous condition. Then pretest was done by asking the students to perform dialog in pairs for about 3-5 minutes based on a given situation. Teaching learning process included introduction, core activities, and closing. In introduction the teacher gave motivation, reminded the students to do activities as the teacher instructed optimally, and told the sequence of activities that would be done. The core activities in cycle 1 included playing rummy game with 
certain rules and practicing dialog by giving stimuli and responses based on modified rummy cards in groups of four. While the core activities in the cycle 2 comprised designing rummy cards with teacher's guidance, playing rummy game with specified rules, and practicing dialog by giving stimuli and responses based on modified rummy cards in groups of three. As closing, the teacher reviewed the lesson and gave necessary feedback. For posttest, both in first and second cycle, the students were asked to perform dialog based a given situation in pair. Besides, the students were given self-assessment test to know how high the students did activities after being given treatment.

Observing

The teacher as well as the collaborator observed what happened when the teaching and learning process were running in the classroom. Furthermore, they focused more about students' activities in listening, asking questions, answering question or responding, repeating speech model, taking turn, making a note, initiating or proposing, and giving comment. The teacher as well as the collaborator took note the necessary things which were found while teaching and learning process were in progress.

\section{Reflecting}

In this step, the researcher did reflection toward what had been achieved during the teaching and learning process. The researcher identified and analyzed the goodness and weakness found during the teaching and learning process. After that the researcher anticipated and made necessary plan for improvement done in the next activities. 


\section{Discussion}

\section{Research Finding in Cycle 1}

Based on the teacher and collaborator's observation in cycle 1, majority of the students did activities intensively as the teacher had instructed. They listened to what the teacher and other students told attentively. They were active in asking and answering questions or giving response. They repeated speech model enthusiastically, they tried to take every turn they got. They made a note on necessary thing. They also braved to initiate or propose as well as to give comment. From the result of self- assessment test, it revealed the students' learning activities grade as in the table 1 below.

Table 1

Students' learning Activities in Cycle 1

\begin{tabular}{|c|l|c|c|c|}
\hline No & \multicolumn{1}{|c|}{$\begin{array}{c}\text { Learning } \\
\text { Activity Grade }\end{array}$} & Scores & $\begin{array}{c}\text { Number Of } \\
\text { Student }\end{array}$ & Percentage \\
\hline 1. & Very low & $1-7$ & 0 & $0 \%$ \\
2. & low & $8-13$ & 0 & $0 \%$ \\
3. & Fair & $14-19$ & 7 & $18.4 \%$ \\
4. & High & $20-25$ & 29 & $76.3 \%$ \\
5. & Very High & $26-32$ & 2 & $5.3 \%$ \\
\hline & Average Score & 21.6 & & $67.4 \%$ \\
\hline
\end{tabular}

Based on the table above, it indicated that there was no student with very low and low learning activities, students with fair learning activities were 7 (18.4\%), students with high learning activities were 29 (76.3\%), students with very high learning activities were $2(5.3 \%)$. The 
average score of students' learning activities was $21.6(67.4 \%)$.

Furthermore, the comparison of students' learning activities between cycle 1 and previous condition could be shown in the table 2 below.

Table 2

Comparison of the Students' Learning Activities between cycle 1 and Previous Condition

\begin{tabular}{|l|c|c|c|}
\hline \multicolumn{1}{|c|}{$\begin{array}{c}\text { Learning } \\
\text { Activity }\end{array}$} & \multicolumn{2}{|c|}{ Number of Students } & \multirow{2}{*}{ Increase/ } \\
Grade & $\begin{array}{c}\text { Previous } \\
\text { Condition }\end{array}$ & Cycle 1 & Decrease \\
\hline Very Low & 0 & 0 & 0 \\
Low & 4 & 0 & 4 \\
Fair & 21 & 7 & 14 \\
High & 13 & 29 & 16 \\
Very High & 0 & 2 & 2 \\
\hline
\end{tabular}

Based on the table above it was shown that there was no student with very low learning activities in the previous condition. The number of students with low learning activities decreased 4 from 4 in the previous condition to 0 in cycle 1 , the number of students with fair learning activities decreased 14 from 21 in the previous condition to 7 in cycle 1 , the number of students with high learning activities increased 16 from 13 in the previous condition to 29 in cycle 1 , and the number of students with very high learning activities increased 2 from 0 in the previous condition to 2 in cycle 2 .

Besides, the scores of English dialog skill in cycle 1 could be shown in the table 3 below. 
Table 3

Scores of English Dialog Skill in Cycle 1

\begin{tabular}{|c|l|c|}
\hline No & \multicolumn{1}{|c|}{ Explanations } & Scores \\
\hline 1 & Highest score & 88 \\
2 & Lowest score & 69 \\
3 & Average score & 76.6 \\
\hline
\end{tabular}

Based on the table above it was known that the highest score of English dialog skill was 88, the lowest score of English dialog skill was 69 and the average score of English dialog skill was 76.6. In addition from 38 students, 36 students had reached passing grade and 2 students had not reached passing grade yet.

In addition, the comparison of English dialog skill scores between Cycle 1 and the previous condition could be shown in the table 4 below.

Table 4

Comparison of English Dialog Skill Scores between Cycle 1 and Previous Condition

\begin{tabular}{|c|l|c|c|c|}
\hline \multirow{2}{*}{ No } & \multirow{2}{*}{ Explanations } & \multicolumn{2}{|c|}{ Scores } & \multirow{2}{*}{ Increase/Decrease } \\
\cline { 3 - 4 } & & $\begin{array}{c}\text { Previous } \\
\text { Condition }\end{array}$ & Cycle 1 & \\
\hline 1 & Highest score & 81 & 88 & 7 \\
2 & Lowest score & 63 & 69 & 6 \\
3 & Average score & 72.7 & 76,6 & 3.9 \\
\hline
\end{tabular}

Based on the table above, it was known that the highest score increased 7 from 81 in the previous condition to 88 in cycle 1, the lowest score increased 6 from 63 in the previous condition to 69 in cycle 1, and 
the average score increased 3,9 from 72.7 in the previous condition to 76.6 in cycle 1. Bisides, the students who reached the passing grade also increased $8(21 \%)$ from $28(74 \%)$ students in the previous condition to $36(95 \%)$ students in cycle 1 . Superficially, both students' learning activities and students' English dialog skill improved a lot, however the determined target namely the average score of dialog skill was 77 had not been reached yet therefore it was continued to cycle 2 .

\section{Research Finding in Cycle 2}

Based on the teacher and collaborator's observation in cycle 2, all students did activities intensively as the teacher had instructed. They listened to what the teacher and other students told more attentively. They were more active in asking and answering questions or giving response. They all repeated speech model enthusiastically. They were ready to take every turn they got. They made a note on necessary thing. They were more confident and brave to initiate or propose as well as give comment. From the result of self assessment test, it revealed the students' learning activities grade as in table 5 below.

Table 5

Students' learning Activities in Cycle 2

\begin{tabular}{|c|l|c|c|c|}
\hline No & $\begin{array}{c}\text { Learning } \\
\text { Activity Grade }\end{array}$ & Scores & $\begin{array}{c}\text { Number Of } \\
\text { Student }\end{array}$ & Percentage \\
\hline 1. & Very low & $1-7$ & 0 & $0 \%$ \\
2. & low & $8-13$ & 0 & $0 \%$ \\
3. & Fair & $14-19$ & 2 & $5.3 \%$ \\
4. & High & $20-25$ & 30 & $78.9 \%$ \\
5. & Very High & $26-32$ & 6 & $15.8 \%$ \\
\hline & Average Score & 22.6 & & $70.6 \%$ \\
\hline
\end{tabular}


Based on the table above, it indicated that there was no student with very low and low learning activities, students with fair learning activities were $2(5.3 \%)$, students with high learning activities were 30 (78.9\%), students with very high learning activities were $6(15.8 \%)$. The average score of students' learning activities was 22.6 (70.6\%).

Furthermore, the comparison of students' learning activities between cycle 2 and cycle 1 could be shown in the table 6 below.

Table 6

Comparison of the Students' Learning Activities between Cycle 1 and Cycle 2

\begin{tabular}{|l|c|c|c|}
\hline \multirow{2}{*}{$\begin{array}{c}\text { Learning } \\
\text { Activity Grade }\end{array}$} & \multicolumn{2}{|c|}{ Number of Students } & \multirow{2}{*}{ Increase/Decrease } \\
\cline { 2 - 4 } & Cycle 1 & Cycle 2 & \\
\hline Very Low & 0 & 0 & 0 \\
Low & 0 & 0 & 0 \\
Fair & 7 & 2 & 5 \\
High & 29 & 30 & 1 \\
Very High & 2 & 6 & 4 \\
\hline
\end{tabular}

Based on the table above it was shown that there was no student with very low and low learning activities both in cycle 1 and in cycle 2, the number of students with fair learning activities decreased 5 from 7 in cycle 1 to 2 in cycle 2, the number of students with high learning activities increased 1 from 29 in cycle 1 to 30 in cycle 2 , and the number of students with very high learning activities increased 4 from 2 in cycle 1 to 6 in cycle 2 .

Besides, the scores of English dialog skill in cycle 2 could be shown in the table 7 below. 
Table 7

Scores of English Dialog Skill in Cycle 2

\begin{tabular}{|c|l|c|}
\hline No & \multicolumn{1}{|c|}{ Explanations } & Scores \\
\hline 1 & Highest score & 94 \\
2 & Lowest score & 75 \\
3 & Average score & 78.5 \\
\hline
\end{tabular}

Based on the table above it was known that the highest score of English dialog skill was 94, the lowest score of English dialog skill was 75 and the average score of English dialog skill was 78.5. In addition, all students had reached passing grade. Furthermore, the comparison of English dialog skill scores between Cycle 2 and Cycle 1 could be shown in the table 8 below.

Table 8

Comparison of English Dialog Skill Scores between Cycle 1 and 2

\begin{tabular}{|c|l|c|c|c|}
\hline \multirow{2}{*}{ No } & \multirow{2}{*}{ Explanations } & \multicolumn{2}{|c|}{ Scores } & Increase/ \\
\cline { 3 - 4 } & & Cycle 1 & Cycle 2 & Decrease \\
\hline 1 & Highest score & 88 & 94 & 6 \\
2 & Lowest score & 69 & 75 & 6 \\
3 & Average score & 76.6 & 78,5 & 1.9 \\
\hline
\end{tabular}

Based on the table above, it was known that the highest score increased 6 from 88 in cycle 1 to 94 in cycle 2, the lowest score increased 6 from 69 in cycle 1 to 75 in cycle 2, and average score increased 1,9 from 76.6 in cycle 1 to 78.5 in cycle 2 . Besides, the students who reached the passing grade also increased $2(5.3 \%)$ from $36(94.7 \%)$ students in cycle 1 to $38(100 \%)$ students in cycle 2 . 
Moreover, the comparison of students' learning activities between cycle 2 and previous condition could be shown in the table 9 below.

Table 9

Comparison of the Students' Learning Activities between cycle 2 and Previous Condition

\begin{tabular}{|c|c|c|c|}
\hline \multirow[b]{2}{*}{$\begin{array}{c}\text { Learning } \\
\text { Activity Grade }\end{array}$} & \multicolumn{2}{|c|}{ Number of Students } & \multirow[b]{2}{*}{ Increase/Decrease } \\
\hline & $\begin{array}{c}\text { Previous } \\
\text { Condition }\end{array}$ & Cycle 2 & \\
\hline Very Low & 0 & 0 & 0 \\
\hline Low & 4 & 0 & 4 \\
\hline Fair & 21 & 2 & 19 \\
\hline High & 13 & 30 & 17 \\
\hline Very High & 0 & 6 & 6 \\
\hline
\end{tabular}

Based on the table above it was shown that there was no student with very low learning activities both in the previous condition and in cycle 2 , the number of students with low learning activities decreased 4 from 4 in the previous condition to 0 in cycle 2 , the number of students with fair learning activities decreased 19 from 21 in the previous condition to 2 in cycle 2 , the number of students with high learning activities increased 17 from 13 in the previous condition to 30 in cycle 2 , and the number of students with very high learning activities increased 6 from 0 in the previous condition to 6 in cycle 2 .

In addition, the comparison of English dialog skill scores between Cycle 2 and the previous condition could be shown in the table 10 below. Table 10 
Comparison of English Dialog Skill Scores between Cycle 2 and Previous Condition

\begin{tabular}{|c|c|c|c|c|}
\hline \multirow[b]{2}{*}{ No } & \multirow[b]{2}{*}{ Explanations } & \multicolumn{2}{|c|}{ Scores } & \multirow[b]{2}{*}{ Increase/Decrease } \\
\hline & & $\begin{array}{l}\text { Previous } \\
\text { Condition }\end{array}$ & Cycle 2 & \\
\hline 1 & Highest score & 81 & 94 & 13 \\
\hline 2 & Lowest score & 63 & 75 & 12 \\
\hline 3 & $\begin{array}{l}\text { Average } \\
\text { score }\end{array}$ & 72.7 & 78,5 & 5.8 \\
\hline
\end{tabular}

Based on the table above, it was known that the highest score increased 13 from 81 in the previous condition to 94 in cycle 2, the lowest score increased 12 from 63 in the previous condition to 75 in cycle 2, and the average score increased 5,8 from 72.7 in the previous condition to 78.5 in cycle 2 . Besides, the students who reached the passing grade also increased $10(26.3 \%)$ from $28(73.7 \%)$ students in the previous condition to $38(100 \%)$ students in cycle 2 . In short, the students' learning activities, students' English dialog skill, and number of students who reached passing grade increased significantly.

\section{Conclusion}

After the researcher did an action research by using rummy game method to improve students' learning activities and skill in English dialog as planned before, it was known that there was significant improvement in students' learning activities and English dialog skill during the teaching and learning process. 


\section{References}

Anita. 2002. Cooperative Learning. Jakarta: PT Grasindo

BNSP. 2006. Standar Kompetensi dan Kompetensi Dasar Bahasa Inggris SMA/MA. Jakarta: Departemen Pendidikan Nasional

Burns, Anne.1999. Collaborative Action Research for English Language

Teachers. United Kingdom: Cambridge University Press

Oemar.2008. Kurikulum dan Pembelajaran. Jakarta: PT Bumi Aksara

Richard.2001. Approaches and Methods in Language Teaching. United

States of America: Cambride University Press

Sardiman.1990. Interaksi dan Motivasi Belajar Mengajar. Jakarta:

Rajawali

Sudarwati. 2007. Look Ahead 2: An English Course for Senior High

School Students. Jakarta: Penerbit Erlangga

Sutopo. 2006. Metode Penelitian Kualitatif. Surakarta: Universitas Sebelas Maret.

Undang-Undang No. 20 Tahun 2003 tentang Sistem Pendidikan Nasional 
